\title{
Comparison of Coagulant Dose (Poly Aluminum Chloride) Use in The Water Treatments Process of Kalimalang River
}

\author{
Deniela Flora Mariyne Wongso Diharjo ${ }^{1}$ Jannie $^{2 *}$, Wahyu Sekti Retno Permatasari, \\ Temmy Wikaningrum ${ }^{4}$ \\ ${ }^{1,2,3,4}$ Environmental Engineering, Faculty of Engineering, President University, Cikarang 17550, Indonesia \\ *Koresponden email: jannie.wind.04@ gmail.com
}

Received: January 9, 2022

Accepted: January 25, 2022

\begin{abstract}
River has a vital role to fulfill the water needs of the community. In the water bodies, the small suspended particles, also known as colloids, with the small weight and stability in the water bodies they have, they cannot be settled or eliminated naturally. There are some concerns regarding colloid removal in Kalimalang river, such as increase in water turbidity resulting the decrease in the river water quality as a water source and disruption of the ecosystem in the river. The experiment used poly-aluminum chloride (PAC) as the coagulant and jar test method which contains coagulation-flocculation process. This aims to determine optimal dosage of PAC to reduce the turbidity and $\mathrm{pH}$ value of water sample that relate to the regulation of water quality standard for sanitary hygiene, which is regulated by law No 32 Year 2017. The optimum dose for this experiment is $2 \mathrm{mg} / \mathrm{L}$ PAC 0.5 percent as the sample achieved the lowest average of turbidity that is $0.02 \mathrm{NTU}$ with the average of $\mathrm{pH}$ is 7 , indicating that the sample meets the quality standards of Environmental Health Quality Standards for sanitary hygiene purposes.
\end{abstract}

Keywords: Poly-Aluminum Chloride, coagulation, flocculation, $\mathrm{pH}$, turbidity

\begin{abstract}
Abstrak
Sungai sebagai peran vital dalam memenuhi kebutuhan air masyarakat. Di dalam badan air, partikel-partikel kecil tersuspensi yang disebut juga koloid, yang karena bobotnya yang kecil dan stabilitasnya di badan air, tidak dapat mengendap atau dihilangkan secara alami. Ada beberapa kekhawatiran mengenai pembuangan koloid di sungai Kalimalang, seperti air semakin keruh yang mengakibatkan penurunan kualitas air sungai sebagai sumber air dan terganggunya ekosistem sungai. Penelitian ini menggunakan poli-aluminium klorida (PAC) sebagai koagulan dan metode jar test yang mengandung proses koagulasi-flokulasi untuk menentukan dosis PAC yang optimal untuk mengurangi kekeruhan dan nilai $\mathrm{pH}$ sampel air yang berhubungan dengan pengaturan kualitas air. standar higiene sanitasi diatur dalam undang-undang No 32 Tahun 2017. Dosis optimum untuk percobaan ini adalah $2 \mathrm{mg} / \mathrm{L}$ PAC 0,5 persen karena sampel mencapai rata-rata kekeruhan terendah 0,02 NTU dan rata-rata $\mathrm{pH} 7$, menunjukkan sampel memenuhi baku mutu dari regulasi Baku Mutu Kesehatan Lingkungan untuk keperluan higiene sanitasi.
\end{abstract}

Kata Kunci: Poli-Aluminium Klorida, koagulasi, flokulasi, pH, kekeruhan

\section{Introduction}

In the water bodies, the small suspended particles, also known as colloids, with the small weight and stability in water bodies they have, they cannot be settled or eliminated naturally. These particles are stable and contribute to water turbidity [1]. In this study, Kalimalang River in Bekasi regency has a vital role for community. Thus, it is important to keep the river to have a good condition and to treat the river water as clean water source before it is used by the community

On the water treatment, there are several processes to reduce suspended solid (colloid) from water by using the application of chemical coagulants. The chemical coagulation process is regarded as a legitimate method, as determined by the hydrolyzed species of inorganic coagulants under various raw water and coagulation circumstances. Adsorption, complexation, and coprecipitation are the major methods for heavy metal elimination [2]. In this study, the chemical coagulant used organic coagulants which is Poly Aluminum Chloride (PAC) that has benefit in some applications, in which the Floc generated is denser and settles faster than alum [3]. Poly Aluminum Chloride (PAC) which comes from chemical material and categorized as cationic polymer coagulant [4], on coagulation-flocculation. PAC is defined as a long chain complex polymer $\mathrm{Al}_{\mathrm{m}}(\mathrm{OH})_{\mathrm{n}}(\mathrm{Cl}) 3_{\mathrm{m}-\mathrm{n}}$ [5]. Polymers have a higher molecular weight and greater density than monomers, yet the size is smaller than monomer's [6]. As a result, PAC chemicals react more readily with 
water-borne particles, and the coagulation-flocculation process with PAC does not necessitate huge concentrations.

Coagulation - flocculation is a turbidity - reduction technique in which colloids in water are destabilized so that they can agglomerate and be physically removed [7]. The coagulation and flocculation process removes TSS by adding a coagulant and rapidly stirring it to neutralize (destabilize) suspended particles and colloids in water that have a negative charge and are less than $1 \mu \mathrm{m}$ in size, forming microflocs that are not visible to the naked eye and range in size from 1 to $100 \mu \mathrm{m}$. Brownian force causes microflocs to collide, and subsequently they bind together to form larger aggregates (peri-kinetic flocculation) [8].

The effected suspension or solution needs coagulation process with the purpose to destabilization or address the factors which increase the stability of a particular system. After the coagulation process, flocculation process is needed to aggregate the destabilized particles from coagulation process to have contacts into settle able flocs. Temperature, $\mathrm{pH}$, effluent quality, dose, and coagulant type are all elements that impact coagulation - flocculation [9].

In Indonesia, the regulation of water quality standard for sanitary hygiene is regulated by law No 32 Year 2017 regarding "Environmental Health Quality Standards And Water Health Requirements For Sanitation Hygiene Purposes, Swimming Pools, Per Aqua Solutions, And Public Bathings". In the Article 1, Water for Sanitary Hygiene Purposes is water of a certain quality used for daily purposes in which the quality is different from the quality of drinking water [10]. Physical, biological, and chemical parameters in the form of mandatory and optional parameters are included in Environmental Health Quality Standards for sanitary hygiene reasons. Additional parameters are only required to be checked if the geohydrological conditions indicate a potential pollution associated with additional parameters. Mandatory parameters must be checked on a regular basis in compliance with the requirements of laws and regulations, whereas additional parameters are only necessary to be checked if the geohydrological conditions indicate a potential pollution associated with additional parameters.

Table 1. Mandatory physical parameter

\begin{tabular}{lccc}
\hline No. & Mandatory Parameter & Unit & Quality Standards (Maximum) \\
\hline 1. & Turbidity & NTU & 25 \\
2. & Color & TCU & 50 \\
3. & Total dissolved solids & $\mathrm{mg} / \mathrm{l}$ & 1000 \\
4. & Temperature & ${ }^{\circ} \mathrm{C}$ & Air temperature \pm 3 \\
5. & Taste & & No taste \\
6. & Odor & & No odor \\
\hline
\end{tabular}

Source : Menteri Kesehatan Republik Indonesia [10]

Table 2. Mandatory biology parameter

\begin{tabular}{lccc}
\hline No. & Mandatory Parameter & Unit & Quality Standards (Maximum) \\
\hline 1. & Total coliform & CFU/100 ml & 50 \\
2. & $E$. coli & CFU $/ 100 \mathrm{ml}$ & 0 \\
\hline
\end{tabular}

Source: Menteri Kesehatan Republik Indonesia [10]

Table 3. Mandatory and additional chemical parameter

\begin{tabular}{lccc}
\hline No. & Parameter & Unit & Quality Standards (Maximum) \\
\hline Mandatory & & $\mathrm{mg} / \mathrm{L}$ & $6.5-8.5$ \\
1. & $\mathrm{pH}$ & $\mathrm{mg} / \mathrm{L}$ & 1 \\
2. & Iron & $\mathrm{mg} / \mathrm{L}$ & 1.5 \\
3. & Fluoride & $\mathrm{mg} / \mathrm{L}$ & 500 \\
4. & $\mathrm{CaCO}_{3}$ & $\mathrm{mg} / \mathrm{L}$ & 0.5 \\
5. & Manganese & $\mathrm{mg} / \mathrm{L}$ & 10 \\
6. & Nitrate & $\mathrm{mg} / \mathrm{L}$ & 1 \\
7. & Nitrite & $\mathrm{mg} / \mathrm{L}$ & 0.1 \\
8. & Cyanide & $\mathrm{mg} / \mathrm{L}$ & 0.05 \\
9. & Detergent & $\mathrm{mg} / \mathrm{L}$ & 0.1 \\
10 & Total pesticide & & \\
\hline Additional & & $\mathrm{mg} / \mathrm{L}$ & 0.001 \\
\hline 1. & Mercury & $\mathrm{mg} / \mathrm{L}$ & 0.05 \\
2. & Arsenic & $\mathrm{mg} / \mathrm{L}$ & 0.005 \\
3. & Cadmium & & \\
\hline
\end{tabular}




\begin{tabular}{lccc}
\hline 4. & Chromium (Valence 6) & $\mathrm{mg} / \mathrm{L}$ & 0.05 \\
5. & Selenium & $\mathrm{mg} / \mathrm{L}$ & 0.01 \\
6. & Zinc & $\mathrm{mg} / \mathrm{L}$ & 15 \\
7. & Sulfate & $\mathrm{mg} / \mathrm{L}$ & 400 \\
8. & Lead & mg/L & $\mathbf{0 . 0 5}$ \\
\hline
\end{tabular}

Source: Menteri Kesehatan Republik Indonesia [10]

In this study, the objective of experiment is to determine the optimum coagulant (PAC) dose for water sample through turbidity and $\mathrm{pH}$ measurement.

\section{Material and Method}

The method used in this paper refers to the literature review from published article employing quantitative method to analyze the data comparison. The data collected from the laboratory practicum "Jar Test of Coagulation and Flocculation" have been done previously.

\subsection{Water Sample Collection}

The source of water sample collected from two-point location of Kalimalang River performs different level of turbidity. To assure that the water sample was homogeneous before the test, both of the water sample were mixed using agitator mixer in different bucket until the sample blended well. The turbidity and $\mathrm{pH}$ level are listed in the Table 4.

Table 4. Initial value of sample

\begin{tabular}{ccc}
\hline Sample & Turbidity & $\mathrm{pH}$ \\
\hline I & 323 & 7.42 \\
II & 293 & 7 \\
\hline \multicolumn{3}{c}{ Source: Research data, 2021 }
\end{tabular}

\subsection{Coagulation - Flocculation}

Coagulation is the process to aggregate the colloid particle and small-suspended matters. It can be done by reducing the zeta potential in the system until the value getting lower than it and it will merge in low stirring. The zeta potential offers information about the charge neutralization status when Zeta potential is zero. Hence, the particle is not mobile, and the particle will be settled [11]. While flocculation is the process by which small flocs generated during the coagulation process combine to form bigger flocs that settle. Distinct types and dosage of coagulants will create different mechanisms of action under different water quality conditions [12]. There are three types of coagulation effects that coagulants and have on colloidal particles in water, for this practicum, we used Poly Aluminum Chloride (PAC) 10\%. PAC knowingly can perform high ability to remove suspended solid (faster kinetic). However, adding the dose requires several parameters to consider [13].

\section{Experimental Procedure}

\section{Dose of Coagulant}

In this laboratory experiment, the coagulant used was Poly Aluminum Chloride or PAC with the concertation of $0.5 \%$. Since the original PAC is $10 \%$, then we needed to dilute by 20 times using distilled water. The calculation:

$$
\begin{aligned}
& 0.5 \% \rightarrow 5 \mathrm{~mL} \rightarrow 100 \mathrm{~mL}=5000 \mathrm{~mL} \\
& (20 \times) \quad 20 \times \\
& m L \text { Sample }=500 \mathrm{~mL}
\end{aligned}
$$

$$
\begin{gathered}
V_{1} C_{2}=V_{2} C_{2} \\
500 \times 5=V_{2} \times 5000 \\
V_{2}=\frac{2500}{5000}=0.5 \mathrm{ml}
\end{gathered}
$$

From this the PAC $5 \%$ is requiring $0.5 \mathrm{~mL}$ in $500 \mathrm{ml}$ of sample volume

\section{Mechanism}

The Jar Test experiment aims to simulate the wastewater treatment plants to remove suspended particles and pollutants in water by coagulation and flocculation to determine and test the right dose of coagulant [14]. From the experiment that had been proceeded, we took $5 \mathrm{~L}$ of water sample from a few rivers in some area and mixing it using the agitators. Then the mixed sample were poured into six different 
beaker glasses with a volume of $500 \mathrm{~mL}$. Moreover, $0.5 \%$ of Poly aluminum chloride (PAC) added with a different volume in each jar (Table 5) and mixed in the mechanical mixer with the speed of $100 \mathrm{rpm}$ for 1 minute (coagulation process) (Fig. 1) and reduced the speed to $40 \mathrm{rpm}$ for 15 minutes (flocculation process) (Fig. 2). It can be identified that all the impurities are trapped and forming flocs. After that, slow the mixer to $0 \mathrm{rpm}$ for 15 minutes, then wait until all the flocs go down into the bottom of the beaker glass. Next, separate $50 \mathrm{~mL}$ from each jar to Erlenmeyer glass and add 1 Erlenmeyer glass consisting of original water to test the turbidity using turbidimeter and $\mathrm{pH}$ using $\mathrm{pH}$ meter. There was also $50 \mathrm{~mL}$ of pure sample which turbidity and $\mathrm{pH}$ were checked as well as the rest of the six samples.

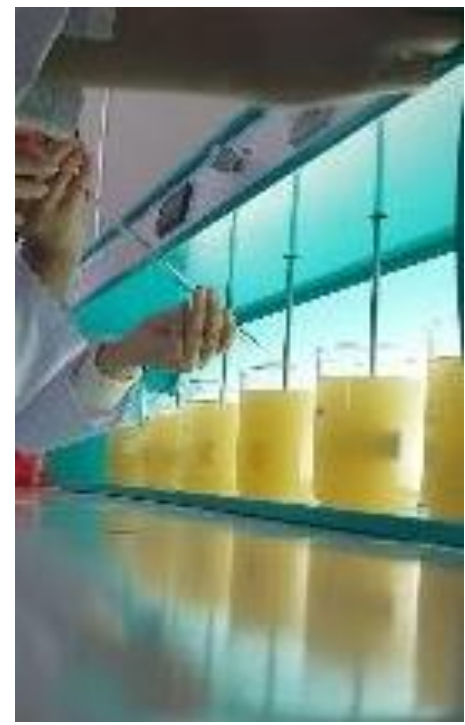

Fig. 1. Coagulation process Source: Research data, 2021

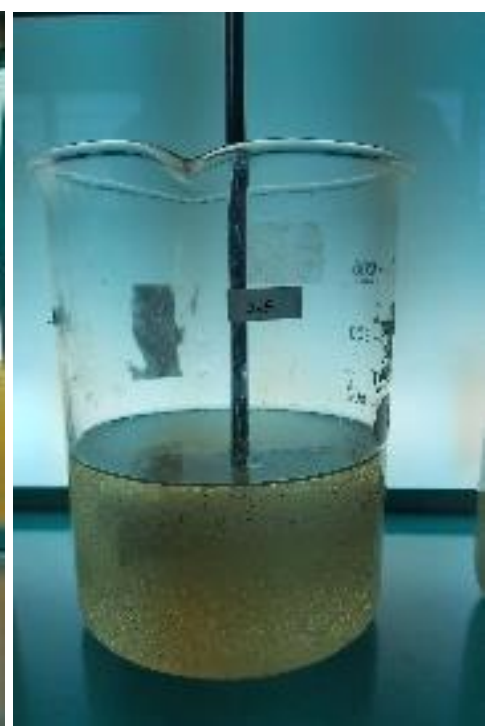

Fig. 2. Flocculation process Source: Research data, 2021

Table 5. PAC dose of sample

\begin{tabular}{lcccccc}
\hline Beaker glass & 1 & 2 & 3 & 4 & 5 & 6 \\
\hline ppm $(\mathrm{mL} / \mathrm{L})$ & 5 & 10 & 15 & 20 & 25 & 30 \\
ppm $(\mathrm{mg} / \mathrm{L})$ & 6 & 12 & 18 & 24 & 30 & 36 \\
PAC dose $0.5 \%(\mathrm{~mL})$ & 0.5 & 1 & 1.5 & 2 & 2.5 & 3 \\
\hline
\end{tabular}

Source: Research data, 2021

\section{Results and Discussion}

In water treatment Coagulation-flocculation is one of the important processes in water treatment where it will affect the upstream treatment (sedimentation, biological process, oxidation process etc.) [15]. In large scale of water treatment, the water quality could be different every time, to add the dose of the coagulant, it is achieved with jar test experiment using the water sample to know what the optimum dose of coagulant is. This jar test experiment employs Poly Aluminum Chloride (PAC) $0.5 \%$ as the coagulant.

\subsection{Effect of Coagulant Dose on Turbidity}

Turbidity is the presence of contaminants in water in the form of colloidal particles or suspensions created by domestic or industrial waste [16]. The contents of the cloudiness of water can contains chemical precipitation or heavy metal such as manganese and iron, or organic particles such as plant waste and organisms [17]. Fig. 3 depicts the influence of the coagulant dosage on the turbidity value of the water sample. The figure shows when the concentration of coagulant is higher or reach the optimum level in which the turbidity 0 NTU on sample I and 0,04 on sample II with the optimum dose is $2 \mathrm{mg} / \mathrm{L}$ PAC $0.5 \%$. Increasing the dose above the optimum level causes a repulsive force between positively charged particles, resulting in a floc deflocculation process which causes the solution to become increasingly cloudy [16], $[18]$. 


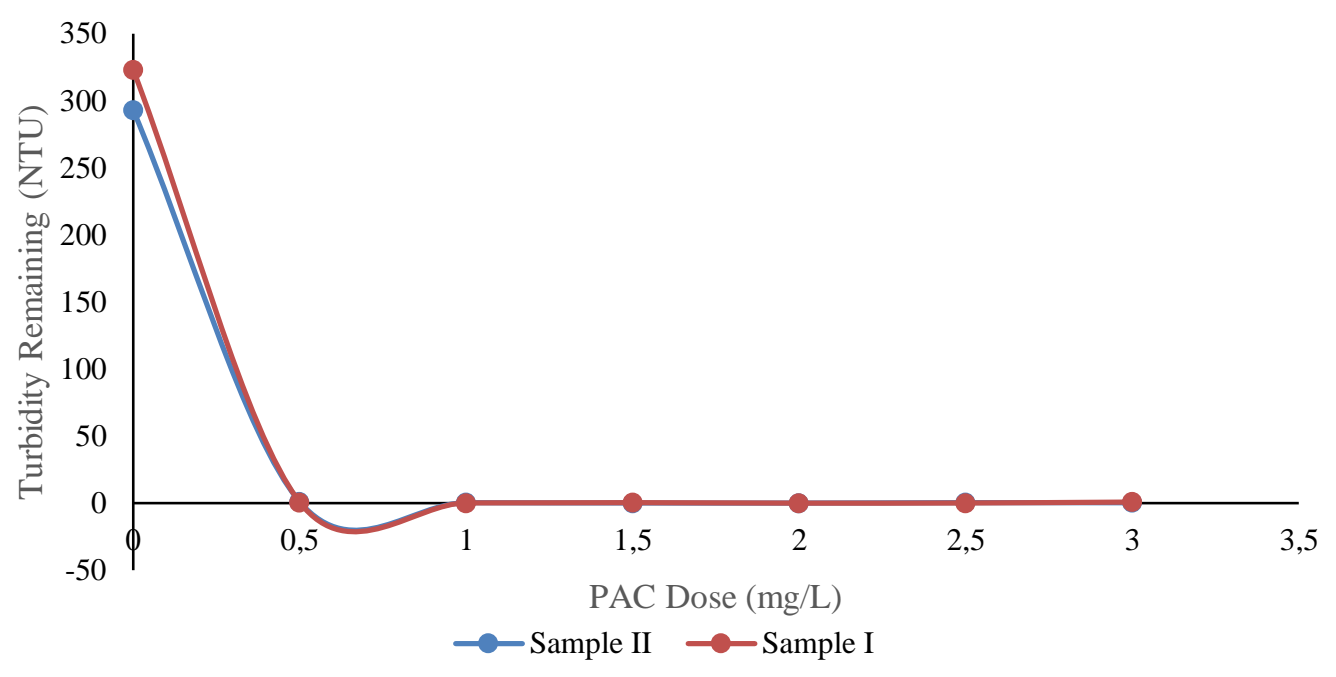

Fig. 3. Turbidity of each PAC dose in water sample Source: Research data, 2021

\subsection{Effect of Coagulant Dose on pH}

A pH meter is used to determine the acidity or alkalinity of a solution. The most effective use of PAC is between the $\mathrm{pH}$ range of 6-9. Based on Fig. 4, the optimum dose is $2 \mathrm{mg} / \mathrm{L} \mathrm{PAC} 0.5 \%$ with value of $\mathrm{pH}$ is 7.05 on sample I and 6,94 on sample II or fulfill the require of standard of $\mathrm{pH}(6.5-8.5 \mathrm{mg} / \mathrm{L})$. The $\mathrm{pH}$ of solution keeps decrease if the PAC dose increases because the $\mathrm{H}+$ ion is getting higher in the solution due to continued adsorption of mono- and the polynuclear hydrolysis process. Thus, the rise in $\mathrm{H}+$ ions, the solution has a low (acidic) $\mathrm{pH}$ [18], [16], [19] .

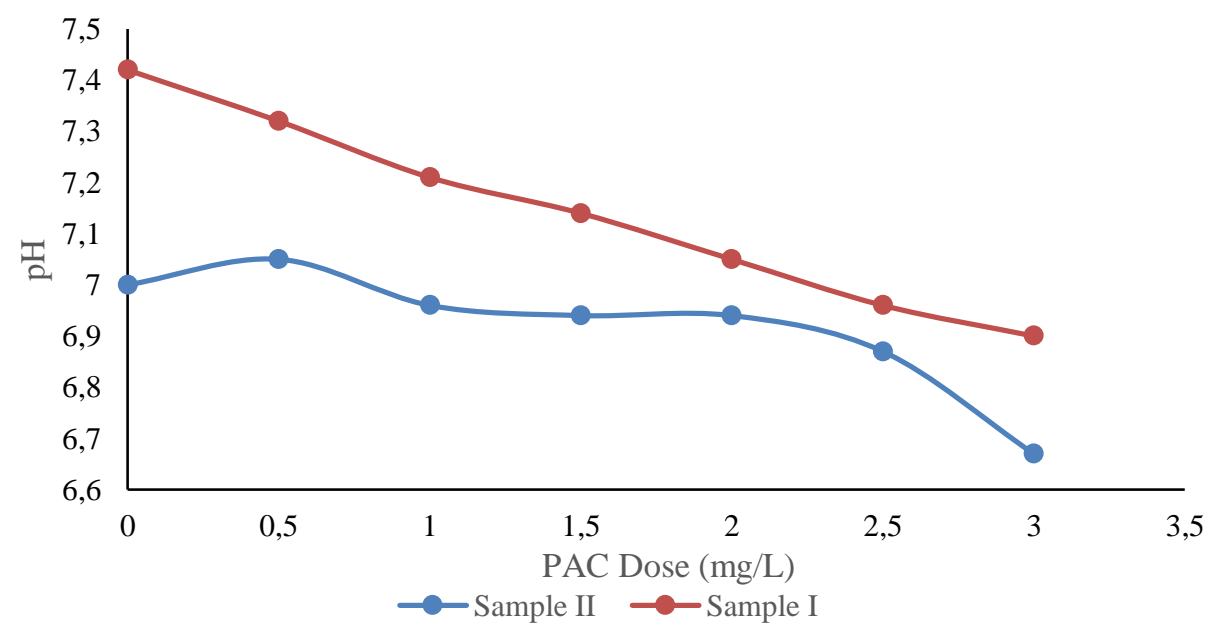

Fig. 4. Turbidity of each PAC dose in water sample

Source: Research data, 2021

\section{Conclusion}

Based on the results of the experiment, it can be stated that the experiment was effective in reducing high turbidity and $\mathrm{pH}$ with the optimal dose of Poly aluminum chloride (PAC) as the coagulant. The optimum dose for this experiment is $2 \mathrm{mg} / \mathrm{L} \mathrm{PAC} 0.5$ percent as the sample achieved the lowest average of turbidity as $0.02 \mathrm{NTU}$ and the average of $\mathrm{pH}$ is 7 , indicating the sample meets the quality standards of Environmental Health Quality Standards for sanitary hygiene purposes. 


\section{Acknowledgment}

The authors convey their highest appreciation to our colleagues at President University, our lecturer, Temmy Wikaningrum and the assistant of laboratory, Putri Laila Anggraina, who inspired, supported, and assisted the research as a partial fulfilment of the requirement of Environmental Chemistry and Laboratory course.

\section{References}

[1] A. D. Zand and H. Hoveldi, "Comparing aluminium sulfate and poly-aluminium chloride (pac) performance in turbidity removal from synthetic water," J. of Applied Biotechnology Reports, vol. 2, no. 3, pp. 287-292, 2015.

[2] X. Tang, H. Zheng, H. Teng, Y. Sun, J. Guo, W. Xie, Q. Yang and W. Chen, "Chemical coagulation process for the removal of heavy metals from water: a review," Desalination and Water Treatment, vol. 57, no. 4, pp. 1733-1748, 2016.

[3] E. K. Tetteh and S. Rathilal, "Chapter 4 - Application of Organic Coagulants in Water and Wastewater Treatment," in Organic Polymers, Croatia, IntechOpen, pp. 51-69, 2019.

[4] D. A. Ardi, "Pengaruh penambahan poly aluminium chloride (pac) terhadap ph dan turbiditas pada air baku di pdam tirtanadi instalasi pengolahan air martubung dengan metode jar test," Laporan Tugas Akhir, Universitas Sumatera Utara, Sumatera Utara, 2018.

[5] N. Wityasari, "Penentuan dosis optimum pac (poly aluminium chloride) pada pengolahan air bersih di ipa Tegal besar pdam Jember," Universitas Jember, Jember, 2015.

[6] Ridwan, R. Afrianita and R. M. Danir, "The effect of coagulants variations in the coagulation unit on the efficiency of raw water turbidity removal sedimentation unit continuous discharges flow (cdf) as a new method," Andalasian International J., vol. 1, no. 2, 2021.

[7] A. Soros, J. E. Amburgey, C. E. Stauber, M. D. Sobsey and L. M. Casanova, "Turbidity reduction in drinking water by coagulation-flocculation with chitosan polymers," J. Water Healt, vol. 17, no. 2, pp. 2014-218, 2019.

[8] S. E. Widiyant, "Optimization of the aluminum sulfate and pac (poly aluminum chloride) coagulant on tello river water treatment," Konversi, vol. 7, no. 1, pp. 1-5, 2018.

[9] J. Bratby, Coagulation and Flocculation in Water and Wastewater Treatment, London: IWA Publishing, 2016.

[10] Menteri Keseatan Republik Indonesia, "Peraturan Menteri Kesehatan Republik Indonesia Nomor 32 Tahun 2017 Tentang Standar Baku Mutu Kesehatan Lingkungan Dan Persyaratan Kesehatan Air Untuk Keperluan Higiene Sanitasi, Kolam Renang, Solus Per Aqua, Dan Pemandian Umum,” 2017. [Online]. Available: http://hukor.kemkes.go.id/uploads/produk_hukum/PMK_No._32_ttg_Standar_Baku_Mutu_Keseh atan_Air_Keperluan_Sanitasi,_Kolam_Renang,_Solus_Per_Aqua_.pdf.

[11] D. Mroczko and I. Zimoch, "The use of Zeta Potential Measurement as a Control Tool of Surface Water Coagulation," J. of Ecological Engineering, vol. 21, no. 3, pp. 237-242, 2020.

[12] S. Wang, J. Fu, C. Zhang and J. Yang, "Chapter 10 - Slurry treatment for shield tunnelling and waste slurry recycling," in Shield Tunnel Engineering, Changsha, https://www.sciencedirect.com/science/article/pii/B9780128239926000102\#: :text=https\%3A//do i.org/10.1016/B978\%2D0\%2D12\%2D823992\%2D6.00010\%2D2, 2021, pp. 491-521.

[13] N. Aziz, N. Effendy and K. T. Basuki, "Comparison of poly aluminium chloride (pac) and aluminium sulphate coagulants efficiency in waste water treatment plant," Inovasi Teknik Kimia, vol. 2, no. 1, pp. 24-31, 2017.

[14] P. B. Tassinari, S. Conaghan, B. Freeland and a. I. W. Marison, "The Jar Test experiment aims to simulate the wastewater treatment plants in order to remove suspended particles and pollutants in water, by coagulation and flocculation to determine and test the right dose of coagulant. From the experiment that has procee," J. of Environmental Engineering, vol. 141, no. 9, 2015.

[15] J.-Q. Jiang, "The role of coagulation in water treatment," Current Opinion in Chemical Engineering, vol. 8, pp. 36-44, 2015. 
[16] N. I. F. Nisa and A. Aminudin, "Pengaruh Penambahan Dosis Koagulan Terhadap Parameter Kualitas Air dengan Metode Jartest," JRST (Jurnal Riset dan Sain Teknologi), vol. 3, no. 2, pp. 6167, 2019.

[17] World Health Organization, "Water quality and health - review of turbidity: Information for regulators and water suppliers," 2017. [Online]. Available: https://apps.who.int/iris/bitstream/handle/10665/254631/WHO-FWC-WSH-17.01-eng.pdf.

[18] N. K. Zaman, R. Rohani, I. I. Yusoff, M. A. Kamsol, S. A. Basiron and A. I. A. Rashid, "Ecofriendly coagulant versus industrially used coagulants: identification of their coagulation performance, mechanism and optimization in water treatment process," Int J Environ Res Public Health, vol. 18, no. 17, 2021.

[19] Z. Daud, H. Awang, A. A. Latif, N. Nasir, M. B. Ridzuan and Z. Ahmad, "Suspended solid, color, cod and oil and grease removal from biodiesel wastewater by coagulation and flocculation processes," Procedia - Social and Behavioral Sciences, vol. 195, no. 3, pp. 2407-2411, 2015. 